\title{
Peter Ackroyd's Chatterton, Thomas Chatterton, and Postmodern Romantic Identities and Attitudes: 'This is essentially a Romantic attitude'
}

The scene is an Indian restaurant called the 'Kubla Khan'; it is the late 1980s. Around the table are Charles, a young poet who is soon to die from a brain tumour, his wife Vivien, and Philip, a librarian friend of theirs. There is also Harriet Scrope, an ageing, cynical novelist who insists on treating the Indian staff as though they are all half-wits, and Andrew Flint, a disillusioned writer who would really rather not be there. Flint has listened with growing impatience to Charles extolling the virtues of poetry, and when Charles declares, 'Poetry is the finer art.[...] It lives', he can take no more:

'This is essentially a Romantic attitude. I am not a Romantic [...]. Don't you realise', he said, 'that nothing survives now? Everything is instantly forgotten. There is no history any more. There is no memory. There are no standards to encourage permanence - only novelty, and the whole endless cycle of new objects. And books are simply objects consumer items to be picked up and laid aside [...]. And poetry is no different. Poetry is disposable too. Something has happened during the course of this generation - don't ask me why. But poetry, fiction, the whole lot-none of it matters any more'.

'If I thought that', Harriet said, ' $I$ 'd shoot myself!' She put her thumb and forefinger up to her right temple. 'Mummy go bang bang', she added, for the waiter's benefit. ${ }^{1}$

Andrew's description of a post-Romantic cultural desert is a familiar one, from Byron's lamentations on the field of Waterloo in Childe Harold's Pilgrimage, to the 'dark corners' of Tennyson's Palace of Art with their 'Uncertain shapes' and 'white-eyed phantasms weeping tears of blood', to Eliot's 'dry sterile thunder without rain' of The Waste Land. ${ }^{2}$ Andrew concurs with this intensely pessimistic view, and in some respects Ackroyd's novel would appear to endorse this. Charles, however, writing poetry, dying young in the 'Kubla Khan', is the epitome of the 'Romantic attitude' that Andrew finds so anachronistic; and he responds to Andrew's speech with a softly spoken, 'Some things do survive' (150). This article will explore the extent to which Ackroyd seems prepared to endorse Charles's resistance to postmodern despair and cynicism in his novel, Chatterton. It also considers the way in which Chatterton himself remains an important focal point when assessing the extent to which postmodernism has survived as a valid concept within theoretical literary debates in the twenty-first century.

Andrew Flint's outburst comes as part of the climax to Charles Wychwood's research into 
the career, and the true fate, of the poet

Thomas Chatterton. Chatterton was understood to have taken his own life in a fit of despair in 1770 when he was seventeen, so Charles's discovery of a portrait that appears to be of Chatterton in middle age has drawn him into an investigation that promises to rewrite English literary history. From faking mediaeval poetry as a teenager in Bristol, it begins to look as though Chatterton went on to fake a large proportion of eighteenth and early nineteenth century canonical British poetry:

'Some of them are by Crabbe, some by Gray, and some by Blake. There are some very famous poems here, but we know now that it is Chatterton imitating all of them'. He squeezed his arm as they walked in smaller and smaller circles. 'Do you see how it works? Joynson persuades Chatterton to fake his own death, then Chatterton forges the great poetry of his time, and then Joynson sells it. Elementary'. He stopped suddenly, and Philip stumbled forward. 'You know', he went on, catching hold of him just before he fell, 'half the poetry of the eighteenth century is probably written by him'. (93-4)

In keeping with a major preoccupation of Romanticism, this scene in the 'Kubla Khan', like the rest of Ackroyd's novel, is dominated by the imminence of death, and the relationship between physical death and 'literary' death. 'Any contemporary work', says Andrew Flint a little later on, 'has a life of about three months. That's all [...]. We can't think of posterity. There is no posterity. At least I can't see it' (150). While we may not share the extent of Flint's pessimism, we may well be tempted to agree that Romanticism failed to survive into the late twentieth century. Behind the façade that would-be Romantics like Charles attempt to sustain, there lies a cynical, materialistic world personified in this novel by the unscrupulous Harriet Scrope, and the art dealers that Charles's wife works for, Maitland and Cumberland. Cumberland's comment on an artist who has recently died sums up his profession: 'That is the trouble with dealers. Death holds no terrors for them. It merely represents a lump sum' (67). Harriet's intention is to steal the Chatterton evidence from Charles and profit by it herself. Ironically, Charles himself seems not to have realised that his own discoveries about Chatterton would seem not only to endorse Andrew Flint's view, but to suggest that Flint's notion of a lost purity of art was never a reality.

Ackroyd's novel offers us two alternative readings of post-Romantic culture. Either it remains intricately attached to the cultural weave of late eighteenth- and early nineteenth-century Romanticism; or it bears witness to the kind of paradigmatic cultural fragmentation that readers of Eliot's Waste Land were asked to contemplate in the 1920s. Structurally, the novel explores these options in a way that has become familiar to readers as a recurring device in postmodernist fiction. The 1980s narrative is juxtaposed to, and frequently destabilised by, interpolations from the past which give rise to parallel narratives. We have Henry Wallis planning and executing his painting, The Death of Chatterton in 1856; we encounter Chatterton in London in 1770, and glimpse him as a child in his native Bristol. The immediate effect of this is to suggest that what Andrew Flint claims as the peculiar vices of his own age ('no history $[\ldots]$ no memory $[\ldots]$ no standards to encourage permanence') are readily to be found in the late eighteenth and nineteenth centuries. Wallis debates the nature of reality with his model for Chatterton, the novelist George Meredith. 'Of course it is all an illusion', says Meredith, 'Art is just another game' (135), and their playing out of that game is accompanied by the love affair between Wallis and Meredith's wife, Mary. 'Art' is the game Chatterton plays in London, as he had 
done with his forgeries of mediaeval drama and poetry that so successfully fooled the literati of his native Bristol. He plans to make two guineas by writing elegies for his recently deceased patron, Alderman Lee, and three guineas for the satires he then intends to write against him (192). 'When I first came to London', Chatterton reflects, 'I thought I had entered a new age of miracles, but these stinking alleys and close packed tenements seem to breed only monsters. Monsters of our own making'. 'Ah, sir', says Mr. Crome the publisher, with an ironic smile, 'I see you are not happy in our enlightened age' (211).

Ackroyd's ironic references to the benefits of 'Enlightenment' in eighteenth-century society cast long shadows across the cultural life of England - and most specifically London -in the 1980s. He achieves this blurring of the traditional periods into which literary history tends to be divided partly by his creation of theatrically eccentric characters like Harriet Scrope in London, Professor Homer Brillo of Valley Forge University whom we only meet through the title of a forthcoming publication, and Mr. Joynson (not to mention Joynson's partner Pat) in Bristol. Could this possibly even be the same Joynson that dealt with the young Chatterton all those years ago? Like Brillo, we never get to meet him; Charles leaves the querulous Pat waiting 'despondently but defiantly, for Mr. Joynson to return to him' (53). Along with Mr. Leno the antiques dealer, figures such as these take the novel into the world of Dickensian fiction even while we follow the twentieth century narrative. Period boundaries are in a state of permanent collapse, a feature of the novel established as soon as the story begins to be told.

Chapter One begins with Charles making his way into Dodd's Gardens. The manifest precision of the reference to the location of Dodd's Gardens ('W14 8QT') serves only to emphasise that the place defies any such precision in relation to time or place, 'the pilasters copied from eighteenth-century façades'. Indeed, at first Charles fails to see the house he is looking for; when it does materialise it is not what it seems: 'At first Charles thought that a hole had been blown in the side of Dodd's Gardens; it was only when he stepped back off the pavement that he saw the curve of the arch, and then the house above it' (7). Once inside, the time warp is emphasised when he meets the owner, Mr. Leno. The antiques and junk of his shop, not to mention the behaviour of Leno and his partner, create the ambience of music-hall where nothing is what it seems. Charles's discovery of the painting that might or might not be the middle-aged Chatterton is forecast by the name of the author of one of the books Charles has come to sell, James Macpherson. Only a few years before Chatterton's fraudulent 'Rowley' manuscripts were to fool the literary élites of Bristol and beyond, Macpherson had convinced many of the same people that he was retrieving genuine fragments of poetry by the ancient bard, Ossian.

So it seems from this that Ackroyd is of the opinion that the world in which nothing may be trusted, in which every appearance, every identity threatens to be illusory, and where ephemerality is the governing principal, is by no means peculiar to the late twentieth century. It is certainly not a condition to be helpfully encapsulated in any late twentieth- or early twenty-first-century 'ism'. Illusion and ephemerality are, in fact, defining ingredients of what we now think of as Romanticism. The Romantics we tend to be most familiar with are frequently to be found defining their art in terms of its elusiveness: the Wordsworthian 'something' of 'Tintern Abbey', the Shelleyan 'unseen Power' of the 'Hymn to Intellectual Beauty', Keats's attempt to commune with the song of the Nightingale, and his melancholy recognition that 'The fancy cannot cheat so well/ As she is famed to $\mathrm{do}^{\prime} .^{3}$ Chatterton arguably played an influential part in the 
evolution of this way of thinking, not least because of his early death, and the consequent aura of mystery that became associated with his identity. He was a powerful presence in the thoughts of the canonical Romantics, and if William Blake's caricaturing of conversations among the aspiring middle class literati of London in An Island in the Moon (c.1784) are to be trusted, we may assume that he was equally a presence there too. ${ }^{4}$ Crucially, this presence is repeatedly defined in terms of absence, and the tragic way in which that absence had come about. While alive, Chatterton had written not just as another person, but as another person from another time. His attempts to make a contribution to the 'enlightened' eighteenth-century world of letters as Thomas Chatterton ended abruptly with his death. This paradoxical perception of absence as presence has been a recurring preoccupation for artists and critics of Romanticism ever since.

William Hazlitt, in his lecture 'On Burns, and the Old English Ballads' (1818) explained the significance of Chatterton in these terms:

It is his name, his youth, and what he might have lived to have done, that excite our wonder and admiration. He has the same sort of posthumous fame that an actor of the last age has - an abstracted reputation which is independent of any thing we know of his works. ${ }^{5}$

Hazlitt is prepared to give Chatterton his due as 'Rowley', but it is the space between Chatterton and Rowley, 'an abstracted reputation', and the haunting silence that exists in that space, 'independent of anything we know of his works', that seems to matter most. In Ackroyd's novel it seems as though that emptiness might be about to be filled by Leno's shop, a place-even if it is a problematical place, suspended above the street rather than anchored at ground level-where there is a portrait that appears to identify a Chatterton who lived, and continued to write his forgeries. If we imagine Hazlitt and his contemporaries stepping back from the literature of the late eighteenth century in order to try and codify it and give it an historically grounded identity (even as Charles necessarily steps back off the pavement to locate Leno's shop), their eyes are drawn to the way the scandal of Chatterton's forgeries negated established notions of intellectual probity, and the way his writing had exposed the authority of elderly connoisseurs as untrustworthy, offering in its place the imaginative brilliance of the humbly born child, a child who wrote in the persona of a poet from another age. The text itself, what was written and how it was written, had become an intensely problematic issue.

Recognising just such a space, just such an absence, in his own experience of writing, Wordsworth famously responded to it in his poem 'Resolution and Independence' with a claim of kinship to Chatterton, 'The sleepless Soul that perish'd in its pride' (and to Burns, the poet Hazlitt linked to Chatterton in his lecture of 1818). The leech gatherer's speech in this poem is an object lesson to which any moralising Augustan poet would have been delighted to have listened. But the old man's prosaic account of how he has overcome his difficulties scarcely register with this Romantic poet. Like Chatterton, Wordsworth is deaf to the words of wisdom located in the place where he is, but alive to a visionary capacity that seems inclined to relocate this encounter in another, distant, strange world, 'the whole Body of the man did seem/ Like one whom I had met with in a dream'. ${ }^{6}$ The texts that matter are those that have not been read, that owe their power to their mysteriousness, their intangibility, their illegibility; to their absence. The book which matters is the book which it 
seems the old man can read, and Wordsworth cannot:

he the Pond

Stirred with his Staff, and fixedly did look Upon the muddy water, which he conn'd As if he had been reading in a book. (1l. 85-8)

Wordsworth's poetry abounds with references to texts that resist reading, from the 'types and symbols of eternity' that haunt him by their sublime illegibility as he descends through the Vale Of Gondo in Book VI of the 1805 Prelude, to the crudely written biography pinned to the coat of the blind beggar in Book VII, to his visionary encounter with the Druids on Salisbury Plain in Book XII. The Druids, we are told, are men who 'covertly expressed/ Their knowledge of the Heavens, and imaged forth/ The constellations'. ${ }^{7}$ Alan Liu has pointed out that in an earlier version of this passage found in 'Salisbury Plain' (1793-4), Wordsworth draws on Chatterton's poem, 'The Battle of Hastings II' $^{\prime}{ }^{8}$

Reference back to Chatterton endorsed the disaffection experienced in various ways by Wordsworth's generation from the neo-classicism of their Augustan forbears and contemporaries. In 1926 Lascelles Abercrombie implied as much when he reflected that those he took to be 'wholly romantic [...] were compelled to invoke the irresponsibility of madness (as in Smart) or the forged authority of antiquity (as in Chatterton and Macpherson), in order to satisfy their peculiar requirements'. ${ }^{9}$ What is important here is Abercrombie's perceptive implication of the knowingness of these individuals. Smart 'invokes' madness; Chatterton and Macpherson adopt forgery as a strategy forced upon them by their determination to assert their true identities. In 'Resolution and Independence', Wordsworth warns us that playing with identity in this fashion is a game that can go tragically wrong. In Adonais, Shelley implies that the cultural crisis for his generation has arisen in no small degree as a consequence of the literary Establishment's determination to repress the political identity of post-Augustan, visionary poets who are, after all, the 'unacknowledged legislators of the World' ${ }^{10}$ In stanza XLV of Adonais he links Chatterton to the republican heroes Algernon Sidney and Lucan. They all met untimely deaths, all are 'inheritors of unfulfilled renown' who exist 'beyond mortal thought,/ Far in the unapparent ${ }^{\prime}{ }^{11}$ Chatterton, through his absence, epitomised what became an essential feature of Romantic ideology, the quest for an 'unseen Power' of Intellectual Beauty, that 'Floats though unseen among us' (ll. 1-2). In the novel, Wallis and Meredith visit the room where Chatterton died, Meredith dealing with the disturbing sense of absence as best he can:

'So this is where the poor poet died'. Meredith turned in a circle, his boots scraping against the worn wooden boards of the floor. 'How does Shelley put it? Rose pale, his solemn agony had not yet faded from him? Nonsense, no doubt'. He felt the bed with his hand and then knelt upon it to look out of the window, across the roof of Furnival's Inn and towards the dome of St. Paul's. 'Your friend's bed is very hard', he said. (137)

It is therefore not surprising that in the early nineteenth century we encounter no shortage of writers, artists, and critics eager to bring Chatterton back to life as the poet, and the victim, they wanted him to be. Ackroyd's novel reminds us that the physical appearance of Chatterton was as hotly debated in the absence of any reliable evidence, as was his presence in relation to his literary, textual absorption into the persona of Rowley. Robert Southey insisted that the profile copied by N. C. Branwhite from a drawing of 1762 by A. Morris bore a close resemblance to Chatterton's sister, and must 
therefore be a trustworthy image. ${ }^{12}$ In the novel, Charles's discovery of the portrait of a middle-aged man who presumably resembles Branwhite's child some thirty years on threatens to set in hand a spectacular reconstruction of English literary history. John Flaxman's familiarity with the Branwhite 'Chatterton' appears to have influenced his depiction of Chatterton as a deluded youth, turning his back on the light of Classicism to take the proffered bowl of poison from the Gothic hag of dark despair. ${ }^{13}$ There is also something of Branwhite's Chatterton in Henrietta Ward's much later Chatterton of 1873, though she spares us the bulbous forehead of genius. ${ }^{14}$ Ward directs our thoughts to the boy's tragic end by reproducing a room that looks very similar to the one shown in Wallis's earlier, iconic, Death of Chatterton. ${ }^{15}$ But while she fills the space left by Chatterton's absence with the sentimental image of a wilful, naughty child caught by his mother, Flaxman uses the same space to execute a satire on what he sees as a degenerative cultural impulse that would have us turn away from the civilising benefits of Classical culture.

In Hawksmoor, a novel published two years before Chatterton in 1985, Peter Ackroyd describes an England of the kind represented in Flaxman's drawing. Under the momentum of the Enlightenment, society is shaking off the last vestiges of a culture dominated by occult forces and the power of magic, and embracing the wisdom that emanates from mathematics and science. The situation is dramatically illustrated when Sir Christopher Wren and Nicholas Dyer visit Stone Henge. While Dyer is 'struck by an exstatic Reverie' in which 'I joined the Earth which flew on like a Stone through the firmament', Wren strides forward, note-book in hand: 'Geometry, he called out, is the Key to this Majesty: if the proportions are right, I calculate that the inner part is an Exagonall Figure raised upon the Bases of four Equilaterall Triangles!'16 In the event,
Hawksmoor eerily insists that the old magic continues to have as dark and disturbing a hold over late twentieth-century society as it had over England in the late seventeenth century. There never will be a mathematical formula capable of describing every aspect of the ancient temple on Salisbury Plain, as Wordsworth (with Chatterton's help) has already affirmed. Similarly, there is no portrait capable of telling us all we would know of the subject it depicts.

No image is finite, none is to be trusted; least of all those that turn up in Leno's junk shop, Maitland and Cumberland's up-market London gallery, or in the London of Peter Ackroyd's novels.

In the world that Ackroyd conjures up, there is absolutely nothing unique, and certainly not 'postmodern', about the indeterminacy of the post-Romantic identity of late twentieth-century culture, or for that matter of Thomas Chatterton himself. The story is one that proposes an endless process of negotiation between perceptions of dream and reality, truth and illusion, good and evil, and reflects on how the past engages with the present, and vice versa. Following the title page and dedication, Ackroyd provides a brief resumé of Chatterton's career (in italics), leaving the precise circumstances in which he took poison carefully unspecified. This is followed by four extracts from later in the novel, though they are not identified as such. There is a passage from Chatterton's story, one from Wallis and Meredith's tale, one featuring Harriet Scrope, and one featuring Charles. You will find the last three of these in the main text, but they are slightly altered as though they have been redrafted. The Chatterton passage is nowhere to be found. It is an absence, a lost page, a fiction within the fiction that eventually proceeds on page 5 to what is headed up 'Part One' of the story. Ackroyd would argue that his story telling tactics here are anything but new; on the contrary, his approach to his subject is a traditional one. In his Preface to 
Thomas Chatterton and Romantic Culture, edited by Nick Groom (1999), he writes:

For many hundreds of years the artists and writers of this country have used a mixture of historical styles as a form of ludic comprehension of the past [...]. It has nothing to do with some 'postmodern' examination of narrative; it is connected, instead, to the enduring consciousness of the nation. ${ }^{17}$

If 'postmodernism' is to mean anything by this analysis, it signifies a late chapter in the evolution of post-Romantic culture.

Post-Romanticism recognises that the identity of Romanticism has only ever been a convenient fiction, a powerful idea, a dream which, as Charles insists shortly before his death, is 'a dream of wholeness, and of beauty' (152). The post-Romantic identity is therefore a dream powerful enough to challenge the omnipotence of death, as Chatterton himself was made to do by others in the various ways we have seen throughout the Romantic period. Wallis's painting illustrates the process. His depiction of Chatterton has been noted for its preoccupation with realism, but it is equally engaged in questioning the finality of the moment. It is incontrovertibly Meredith who lies on the bed, feigning death. Above him is the open window through which we must assume the spirit of Chatterton has taken flight. The trailing arm defines the subject as a victim after the tradition of the Pietà, Christ dying to rise again in a spiritual form more powerful than any mortal manifestation could achieve. But intertextuality also gives the painting its darker side. No viewer at the time would have missed the association with Fuseli's Nightmare (1781), a ubiquitous image which imbues the dream - that dangerous state of absence from consciousness - with terror and sexual perversion..$^{18}$ Wallis's elegiac Chatterton thus assumes undertones of erotic violence and despair in much the same way that Coleridge's 'Kubla Khan' describes 'A sunny pleasure-dome with caves of ice', and contains both 'a deep delight' and 'Ancestral voices prophesying war!'19 The 'Kubla Khan' restaurant is where we began, with Charles insisting, against all the odds, upon his vision of poetic beauty, only to collapse, and before long to die.

With Sam Taylor-Wood's photograph of 1998, Soliloquy 1, it might be thought that we encounter a postmodern response to the evolution of a post-Romantic theme. ${ }^{20}$ With the novel in mind, however, it could be argued that Taylor-Wood is part of a more inclusive, post-Romantic tradition, working yet one more variation on the theme of the Romantic dreamer, his hand trailing in a wash of mildly erotic images that glide beneath his couch. There is, of course, no reason why we should not also call it postmodern if we wish. This, I would suggest, 'is essentially a Romantic attitude' articulated in a language adapted to a post-Romantic era.

Department of English and Performance Studies University of Greenwich

Notes

1. Peter Ackroyd, Chatterton (London, 1987), 149-50. Subsequent page references in the text.

2. Alfred Tennyson, 'The Palace of Art', in Poems and Plays, ed. T. Herbert Warren, revised and enlarged by Frederick Page (Oxford, 1975). T. S. Eliot, The Waste Land, in Collected Poems 1909-1962 (London, 1963), 1.342.

3. John Keats, Ode to a Nightingale in The Complete Poems, ed. John Barnard (Harmondsworth, 1977), $11.73-4$.

4. See The Poems of William Blake, ed. W. H. Stevenson (London, 1971), 42.

5. Selected Writings of William Hazlitt, ed. Duncan Wu (9 vols., 1998), ii. 281.

6. William Wordsworth, 'Resolution and Independence', in Poems in Two Volumes, and Other Poems 1800-1807, ed. Jared Curtis, Cornell Wordsworth Series (New York, 1983), 11.116-7. 
7. William Wordsworth, The Prelude 1799, 1805, 1850, ed. Jonathan Wordsworth, M. H. Abrams, and Stephen Gill (London \& New York, 1979), 11.346-7.

8. Alan Liu, Wordsworth: The Sense of History (Stanford, 1989), 197.

9. Lacselles Abercrombie, Romanticism (London, 1963), 35.

10. Percy Shelley, A Defence of Poetry, in Shelley's Poetry and Prose, ed. Donald H. Reiman and Sharon B. Powers (London, 1977), 508.

11. Percy Shelley, Adonais, in Poetical Works, ed. Thomas Hutchinson (Oxford, 1971), $11.399-400$.

12. Thomas Chatterton, from an engraving after N. C. Branwhite. Frontispiece to John H. Ingram, The True Chatterton (London, 1910).

13. John Flaxman, Thomas Chatterton Taking the Bowl of Poison from the Spirit of Despair (undated engraving). The Lolo Williams Collection, reproduced in Marcel Brion, The Art of the Romantic Era (London, 1966).

14. Henrietta Ward, Chatterton (1873 oil on canvas). City of Bristol Museum and Art Gallery, reproduced in Pamela Gerrish Nunn, Victorian Women Artists (London, 1987).

15. Henry Wallis, The Death of Chatterton, The Tate Britain Gallery, London.

16. Peter Ackroyd, Hawksmoor (London, 1985).

17. Peter Ackroyd, Preface to Thomas Chatterton and Romantic Culture, ed. Nick Groom (Basingstoke, 1999), 2.

18. Henry Fuseli, The Nightmare (1781 oil on canvas), The Detroit Institute of Arts, reproduced in Peter Tomoroy, The Life and Art of Henry Fuseli (London, 1972).

19. S. T. Coleridge, 'Kubla Khan', in Poems, ed. John Beer (London, 1986), 1l. 36, 44, 47.

20. Sam Taylor-Wood, Soliloquy 1 (1998, photograph on paper). The Tate Modern Gallery. 